\title{
Alkali Hydrothermal Synthesis of Zeolite A Using Oxide By-products
}

\author{
Taichi MURAKAMI, ${ }^{2)}$ Yoshiyuki SUGANO, ${ }^{31}$ Tsunetoshi KINAMI, ${ }^{1)}$ Takayuki NARUSHIMA, ${ }^{1)}$ \\ Yasutaka IGUCHI ${ }^{4)}$ and Chiaki OUCHI ${ }^{4)}$
}

1) Department of Materials Processing, Graduate School of Engineering, Tohoku University, Sendai 980-8579 Japan.

2) Institute of Multidisciplinary Research for Advanced Materials, Tohoku University, Sendai 980-8577 Japan.

3) Formerly Graduate Student, Tohoku University. Now at JFE Steel Corp. Chiba 260-0835 Japan.

4) A Emeritus Professor of Tohoku University.

(Received on July 2, 2010; accepted on September 14, 2010)

\begin{abstract}
The alkali hydrothermal synthesis of zeolite $\mathrm{A}$ using oxide by-products such as blast furnace (BF) slag and aluminum dross was investigated. $\mathrm{Na}-\mathrm{P} 1\left(\mathrm{Na}_{6} \mathrm{Al}_{6} \mathrm{Si}_{6} \mathrm{O}_{32} \cdot 12 \mathrm{H}_{2} \mathrm{O}\right)$ was synthesized directly in $\mathrm{NaOH}$ aqueous solution for $86.4 \mathrm{ks}$ at $373 \mathrm{~K}$ using $\mathrm{BF}$ slag, $\mathrm{Al}_{2} \mathrm{O}_{3}$, and $\mathrm{SiO}_{2}$. On the other hand, zeolite A was successfully synthesized by a two-step method including an elution treatment of $\mathrm{Al}_{2} \mathrm{O}_{3}$. Under optimal conditions, the formation ratio of zeolite $A$ in various compounds contained in the product was $56 \%$. The utilization of dross residue squeezed out from the aluminum dross as a raw material to synthesis of zeolite $A$ let this ratio increase to $60 \%$. The heat of water adsorption of the product synthesized by the two-step method using $\mathrm{BF}$ slag, $\mathrm{SiO}_{2}$, and aluminum dross residue was measured, and it was $184 \mathrm{~J} / \mathrm{g}$, being higher than that of commercial zeolite $A$.
\end{abstract}

KEY WORDS: zeolite A; hydrothermal synthesis; heat-storage materials; slag.

\section{Introduction}

Heat storage systems that utilize the heat generated by water adsorption of zeolite can contribute to reducing the difference between the amounts of the electric power consumption in the daytime and nighttime. These systems also contribute to the effective utilization of exhaust heat at low temperatures. ${ }^{1)}$ Zeolite is hydrothermally synthesized by heating raw materials at high temperatures under high pressure for a certain period of time. In general, the raw materials used for the synthesis of zeolite consist of compounds such as $\mathrm{Si}$ or Al oxide (hereinafter described as a Si or Al source, respectively), which are alkali sources for alkali aqueous solutions. Zeolite $\mathrm{A}$, with a composition of $\left\{\mathrm{Na}_{12}\left[\mathrm{Al}_{12} \mathrm{Si}_{12} \mathrm{O}_{48}\right] \cdot 27 \mathrm{H}_{2} \mathrm{O}_{8}\right.$, has a $\mathrm{Si} / \mathrm{Al}$ molar ratio of 1 and contains the largest amount of $\mathrm{Al}$ among various zeolites. It has been reported that the amount of water vapor absorbed was approximately $30 \%$ of the total mass of zeolite $\mathrm{A} .^{2)}$ However, the production cost of zeolite $\mathrm{A}$ is high, which may prevent a practical use of zeolite $A$ as a heat storage material.

In 2008, 78.5 million tons of pig iron were produced in Japan, resulting in 27.3 million tons of blast furnace slag (BF slag) as a by-product, of which $82 \%$ was waterquenched slag and $18 \%$ was slow-cooled slag. Most slag is re-used as raw materials for cement, roadbed, and concrete aggregate. However, the amount of BF slag produced in Japanese steel industry tends to become much higher than the total amount of slag consumption in these fields and therefore, exploring new applications of BF slag has become increasingly important. The major components of $\mathrm{BF}$ slag are $\mathrm{SiO}_{2}, \mathrm{Al}_{2} \mathrm{O}_{3}, \mathrm{CaO}$, and $\mathrm{MgO}$. Since $\mathrm{Ca}$ and $\mathrm{Mg}$ can be substituted for $\mathrm{Na}$ in the synthesis of zeolite $\mathrm{A}$, BF slag may possibly become one of the available raw materials for the synthesis of zeolite. If BF slag can be used as a raw material for the synthesis of zeolite A, the manufacturing cost of zeolite $\mathrm{A}$ is much reduced. If the product synthesized by use of BF slag can be successfully applied to heat-storage materials, this development contributes to saving resources due to the effective recycle use of industrial waste. Other utilizations of zeolite include can also be used for the purification of industrial liquid waste and soil, the humidity control material for buildings, deodorants, and so on.

Many studies on the synthesis of zeolite-type materials by hydrothermal treatment using BF slag have been reported. Tae et al. ${ }^{3)}$ and Yoshikawa et al. ${ }^{4)}$ reported that tobermorite $\left(\mathrm{Ca}_{5} \mathrm{Si}_{6} \mathrm{O}_{18} \mathrm{H}_{2} \cdot 4 \mathrm{H}_{2} \mathrm{O}\right)$ can be synthesized in $\mathrm{NaOH}$ aqueous solution. Kuwahara et $a l^{5)}$ successfully synthesized composite materials of hydroxyapatite and zeolite $\mathrm{X}$ using aqueous solution of $\mathrm{H}_{3} \mathrm{PO}_{4}$ and $\mathrm{NaOH}$ mixture. However, they did not report on the alkali hydrothermal synthesis of zeolite A. We have previously ${ }^{6}$ ) reported the synthesis of zeolite A using water-quenched BF slag. The synthesis of zeolite A was carried out using BF slag, $\mathrm{SiO}_{2}$, and $\mathrm{NaAl}_{2} \mathrm{O}_{4}$, where $\mathrm{BF}$ slag was used to adjust the composition of the raw material. It was elucidated that the most optimum slag composition required to synthesize zeolite A was a molar ratio of $\mathrm{Si} / \mathrm{Al}$ of 1 , and that the content of $\mathrm{CaO}$ 
and $\mathrm{MgO}$ was needed to be reduced down to 15 mass $\%$. The hydrothermal treatment conditions adopted in the previous study were as follows: the temperature range was from 328 to $358 \mathrm{~K}, \mathrm{NaOH}$ solution had a concentration of $1 \mathrm{M}$, and the ratio of the volume of $\mathrm{NaOH}$ solution to the total mass of slag $\left(V_{\text {sol }} / W_{\text {slag }}\right)$ was $15(\mathrm{~mL} / \mathrm{g})$. Commercial reagents were used to adjust the composition of the raw materials.

Waste glass, fly ash, and waste diatomite can be used as a Si source. Many studies ${ }^{7-11)}$ on the synthesis of zeolite-type materials by hydrothermal treatment using fly ash have been reported. However, the synthesized product is zeolite with high $\mathrm{Si} / \mathrm{Al}$ ratio and there are only a few reports on the synthesis of zeolite A as a main product. Hollman et al. ${ }^{10)}$ and Tanaka et al. ${ }^{11)}$ reported the two-step process that consisted of Si elusion from fly ash and hydrothermal synthesis with $\mathrm{NaOH}$.

On the other hand, aluminum dross can be used as an Al source. The so-called aluminum dross can be recovered from the refining process of aluminum and its alloys, and aluminum content in this dross is generally higher than $60 \%$. The residue forms in the recovery process of aluminum dross (hereinafter described as dross residue), and the dust also forms. These contain high levels of $\mathrm{Al}_{2} \mathrm{O}_{3}$ and AIN. 100000 tons per year of the aluminum dross was deposited in landfills in Japan. Furthermore, given the uses of other by-products with aluminum oxide, it is important to discuss whether $\mathrm{Al}_{2} \mathrm{O}_{3}$, which is a poorly water-soluble oxide, can be used as a raw material for the synthesis of zeolite A.

The objectives of this study are to clarify the synthesis conditions of zeolite A using oxide by-products such as water-quenched BF slag and dross residue, and then to evaluate heat capacity of the synthesized zeolite A, taking into account its effective utilization as a heat storage material. First, the optimum synthesis conditions using BF slag, $\mathrm{SiO}_{2}$, and $\mathrm{Al}_{2} \mathrm{O}_{3}$ are investigated. Secondly, synthesizing condition of zeolite A using the dross residue is studied. Finally, the heat of water adsorption of several synthesized products is measured using a Tian-Calvét type calorimeter.

\section{Experimental}

Raw materials used in this study were water-quenched BF slag, dross residue, amorphous $\mathrm{SiO}_{2}$ with $99.9 \%$ purity (Kanto Chem. Ltd.), first-grade $\mathrm{Al}_{2} \mathrm{O}_{3}$ (Wako Pure Chem. Ind. Ltd.), and first-grade $\mathrm{NaAlO}_{2}$ (Wako Pure Chem. Ind. Ltd.). BF slag and the dross residue were supplied from plants of a respective industry in Japan. Their compositions are listed in Tables $\mathbf{1}$ and $\mathbf{2}$, respectively. BF slag was grounded to a powder with a size less than $30 \mu \mathrm{m}$ in an agate mortar.

Zeolite A was synthesized in $\mathrm{NaOH}$ aqueous solution using a ball-milling-type reaction vessel with a volume of $60 \mathrm{~mL}$, in a heater. ${ }^{6}$ ) The composition of the raw materials was adjusted so that the molar ratio of $\mathrm{Si} / \mathrm{Al}$ was 1.0 , and the content of $\mathrm{CaO}$ and $\mathrm{MgO}$ was 15 mass\%. In this study, the direct and two-step synthesis methods were investigated. In the direct synthesis method, $1.0 \mathrm{~g}$ of raw material powders, a number of $240 \mathrm{SiC}$ balls with a diameter of $5 \mathrm{~mm}$, and $15 \mathrm{~mL}$ of $\mathrm{NaOH}$ aqueous solution were put into
Table 1. Chemical compositions of water-quenched blast furnace slag (mass\%).

\begin{tabular}{cccccc}
\hline $\mathrm{SiO}_{2}$ & $\mathrm{Al}_{2} \mathrm{O}_{3}$ & $\mathrm{CaO}$ & $\mathrm{MgO}$ & Total- $\mathrm{Fe}$ & $\mathrm{FeO}$ \\
\hline \hline 33.8 & 14.7 & 42.5 & 6.65 & 0.25 & 0.05 \\
\hline
\end{tabular}

Table 2. Chemical compositions of aluminum dross (mass\%).

\begin{tabular}{ccccc}
\hline Al & AlN & $\mathrm{Al}_{2} \mathrm{O}_{3}$ & $\mathrm{MgAl}_{2} \mathrm{O}_{4}$ & $\mathrm{MgO}$ \\
\hline \hline 33.94 & 32.11 & 9.14 & 20.27 & 4.54 \\
\hline
\end{tabular}

the vessel. $\mathrm{NaOH}$ aqueous solution was prepared by dissolving granular $\mathrm{NaOH}$ powder with purity greater than $96 \%$ into distilled water. The concentration of $\mathrm{NaOH}$ was changed in the range from 1.0 to $3.0 \mathrm{~mol} / \mathrm{L}$. The synthesis temperature and time periods were varied in the ranges from 343 to $403 \mathrm{~K}$ and from 14.4 to $86.4 \mathrm{ks}$, respectively. The two-step synthesis method consists of an elution process of $\mathrm{Al}_{2} \mathrm{O}_{3}$, followed by the synthesis of zeolite $\mathrm{A}$ as the second step. In the $\mathrm{Al}_{2} \mathrm{O}_{3}$ elution step, $\mathrm{Al}_{2} \mathrm{O}_{3}$, the dross residue, a number of $240 \mathrm{SiC}$ balls, and $\mathrm{NaOH}$ aqueous solution were put into the vessel. The elution temperature was $473 \mathrm{~K}$. The concentration of $\mathrm{NaOH}$ was changed in the range from 1.0 to $3.0 \mathrm{~mol} / \mathrm{L}$. The elution time periods were varied in the range from 3.6 to $86.4 \mathrm{ks}$. Subsequently, BF slag and amorphous $\mathrm{SiO}_{2}$ powders were added to the vessel, and the synthesizing was conducted. The synthesis temperature and time periods were varied in the range from 363 to $413 \mathrm{~K}$ and from 3.6 to $43.2 \mathrm{ks}$, respectively. In both the aluminum elusion and synthesizing steps, the rotating velocity of the autoclave vessel was $75 \mathrm{rpm}$.

After the synthesis reaction was terminated, the synthesized products were removed from the vessel. After filtering and washing these products by distilled water, they were dried at the synthesis temperature. Then, the products were analyzed for phase identification of compounds by X-ray diffraction. The ratio of identified phases in the product was determined by the calibration curve method using $\mathrm{MgO}$ as the standard reagent.

The heat of water adsorption was measured using a Tian-Calvét type twin calorimeter. ${ }^{12,13)}$ Figure 1 shows the schematic drawing of the calorimeter made in this study. Two reaction cells, i.e., the working and reference cells, were set up in a copper block held at a constant temperature. In each of these twin units, the difference between the temperature in the reaction cell and the constant temperature in the block was detected using a 96-couple K-type thermopile. The synthesized product was granulated with a diameter of approximately $3 \mathrm{~mm}$ by the addition of colloidal silica. The granulated product with a weight of $0.3 \mathrm{~g}$ was dried at $673 \mathrm{~K}$ for $3.6 \mathrm{ks}$ under vacuum of $10^{-1} \mathrm{~Pa}$, followed by cooling to room temperature. Distilled water with a $1.0 \mathrm{~mL}$ was poured into the cells. After the temperature of the copper block was stabilized at room temperature, the granulated product was dropped into the reaction cell. The enthalpy change accompanied with the reaction of the product with distilled water was defined as the heat of water ad- 


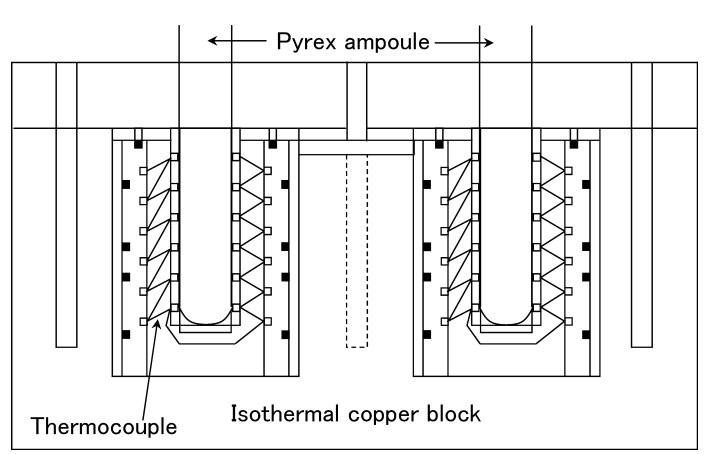

Fig. 1. The schematic diagram of twin calorimeter assembly.

sorption. The calorimeter was calibrated using the measured heat in dilution of $\mathrm{HCl}$ into distilled water.

\section{Results}

\subsection{Synthesis of Zeolite $\mathrm{A}$ Using $\mathrm{Al}_{2} \mathrm{O}_{3}$ as an $\mathrm{Al}$ Source}

Figure 2 shows the XRD patterns of the products obtained by the direct synthesis of zeolite A using BF slag, $\mathrm{SiO}_{2}$, and $\mathrm{Al}$ source from a) $\mathrm{NaAlO}_{2}$ and b) $\mathrm{Al}_{2} \mathrm{O}_{3}$. The alkali hydrothermal treatment was carried out at $373 \mathrm{~K}$ for $86.4 \mathrm{ks}$ in $1 \mathrm{~mol} / \mathrm{L} \mathrm{NaOH}$ solution. Zeolite A was formed using $\mathrm{NaAlO}_{2}$, though small amounts of tobermorite and hydrogarnet $\left(3 \mathrm{CaO} \cdot \mathrm{Al}_{2} \mathrm{O}_{3} \cdot(3-x) \mathrm{SiO}_{2} \cdot 2 x \mathrm{H}_{2} \mathrm{O} \quad(x=0-3)\right)$ were also formed. However, when $\mathrm{Al}_{2} \mathrm{O}_{3}$ was used as $\mathrm{Al}$ source, $\mathrm{Na}-\mathrm{P} 1\left(\mathrm{Na}_{6} \mathrm{Al}_{6} \mathrm{Si}_{6} \mathrm{O}_{32} \cdot 12 \mathrm{H}_{2} \mathrm{O}\right)$ with a $5 / 3$ in $\mathrm{Si} / \mathrm{Al}$ ratio was formed instead of zeolite $\mathrm{A}$, and much of the $\mathrm{Al}_{2} \mathrm{O}_{3}$ powder remained. The higher ratio of $\mathrm{Si} / \mathrm{Al}$ in the solution is attributed to the poor elution ability of $\mathrm{Al}_{2} \mathrm{O}_{3}$. The water adsorption property of $\mathrm{Na}-\mathrm{P} 1$ is less than that of zeolite $\mathrm{A}$, since only a dozen $\mathrm{H}_{2} \mathrm{O}$ molecules can be adsorbed to $\mathrm{Na}-\mathrm{Pl}$, whereas 27 water molecules can be adsorbed to zeolite A.

Figure 3 shows XRD patterns of the products obtained by the two-step synthesis of zeolite A, of which conditions were an elution treatment at $373 \mathrm{~K}$ for $14.4 \mathrm{ks}$ and the hydrothermal treatment at $473 \mathrm{~K}$ for $86.4 \mathrm{ks}$. The concentration of $\mathrm{NaOH}$ in the solution was varied in the range from 1 to $5 \mathrm{~mol} / \mathrm{L}$. The formation of zeolite A was detected under all conditions, though small amounts of tobermorite, hydrogarnet, and sodalite $\left(\mathrm{Na}_{8}\left(\mathrm{AlSiO}_{4}\right)_{6} 2 \mathrm{X} \cdot n \mathrm{H}_{2} \mathrm{O}, \quad \mathrm{X}=\right.$ $1 / 2 \mathrm{CO}_{3}^{2-}, 1 / 2 \mathrm{SO}_{4}^{2-}, \mathrm{Cl}^{-}, \mathrm{OH}^{-}$or $\mathrm{NO}_{3}^{-}$) were also identified. However, the X-ray peak intensity of zeolite A synthesized using $1 \mathrm{M} \mathrm{NaOH}$ solution was considerably lower than that synthesized under other conditions. Furthermore, the amorphous phase was detected. As shown in Fig. 4, the ratio of zeolite $\mathrm{A}$ in the product increases with increasing the concentration of $\mathrm{NaOH}$ and its peak value is observed at $3 \mathrm{~mol} / \mathrm{L}$ of $\mathrm{NaOH}$ concentration, followed by a reduction of its value with a further increase of $\mathrm{NaOH}$ concentration higher than $3 \mathrm{~mol} / \mathrm{L}$. It should be noted that $\mathrm{Al}_{2} \mathrm{O}_{3}$ was not identified for all $\mathrm{NaOH}$ concentrations, suggesting that most of the $\mathrm{Al}$ contained in $\mathrm{Al}_{2} \mathrm{O}_{3}$ was eluted during elution treatment in the first step.

Figure 5 shows the changes in the concentration of $\mathrm{Al}$ ions released from $\mathrm{Al}_{2} \mathrm{O}_{3}$ and the volume ratio of zeolite $\mathrm{A}$ in the product according to the $\mathrm{Al}$ elution time. The product was synthesized at $373 \mathrm{~K}$ for $14.4 \mathrm{ks}$, after elution treatment for various elution time periods at $473 \mathrm{~K}$ in $3 \mathrm{~mol} / \mathrm{L} \mathrm{NaOH}$

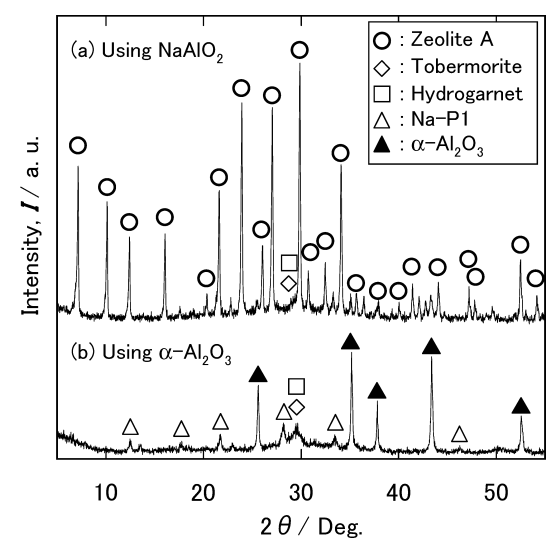

Fig. 2. XRD patterns of products obtained by hydrothermal treatment in use of (a) $\mathrm{NaAlO}_{2}$ and (b) $\mathrm{Al}_{2} \mathrm{O}_{3}$ as $\mathrm{Al}$ source.

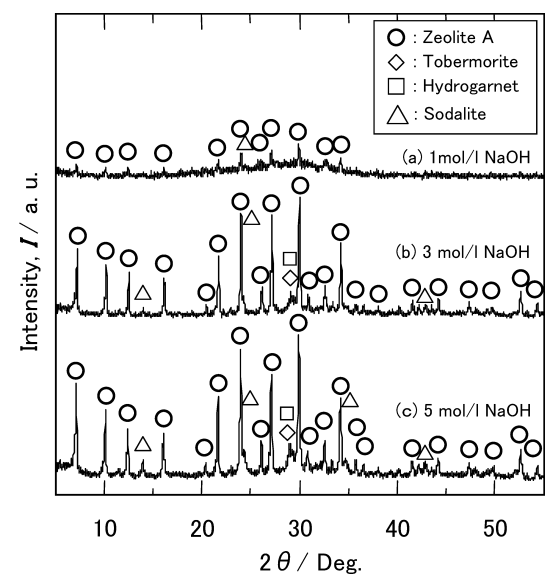

Fig. 3. XRD patterns of products obtained by hydrothermal treatment at $373 \mathrm{~K}$ for $14.4 \mathrm{ks}$ after $\mathrm{Al}$ elution treatment at $473 \mathrm{~K}$ for $86.4 \mathrm{ks}$ in (a) $1 \mathrm{~mol} / \mathrm{L}$, (b) $3 \mathrm{~mol} / \mathrm{L}$ and (c) $5 \mathrm{~mol} / \mathrm{L} \mathrm{NaOH}$ solutions.

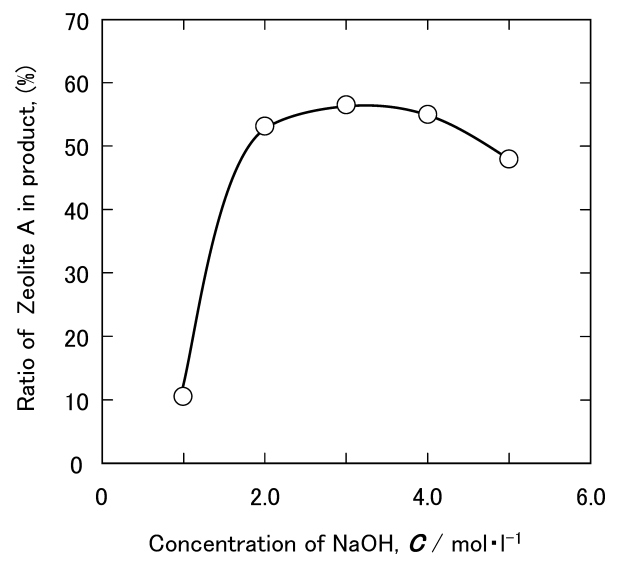

Fig. 4. The effect of $\mathrm{NaOH}$ concentration on the volume ratio of zeolite A in products obtained by hydrothermal treatment at $373 \mathrm{~K}$ for $14.4 \mathrm{ks}$ after $\mathrm{Al}$ elution treatment at $473 \mathrm{~K}$ for $86.4 \mathrm{ks}$.

solution. The dashed line represents the concentration of $\mathrm{Al}$ ions when all the $\mathrm{Al}_{2} \mathrm{O}_{3}$ added in the vessel dissolves in the solution. Al elution from $\mathrm{Al}_{2} \mathrm{O}_{3}$ begins after a short incubation time (less than $10 \mathrm{ks}$ ) and is complete within $18.0 \mathrm{ks}$. No zeolite A formed at the elution time of $7.2 \mathrm{ks}$, and the product only contained $\mathrm{Al}_{2} \mathrm{O}_{3}$ and an amorphous phase. 


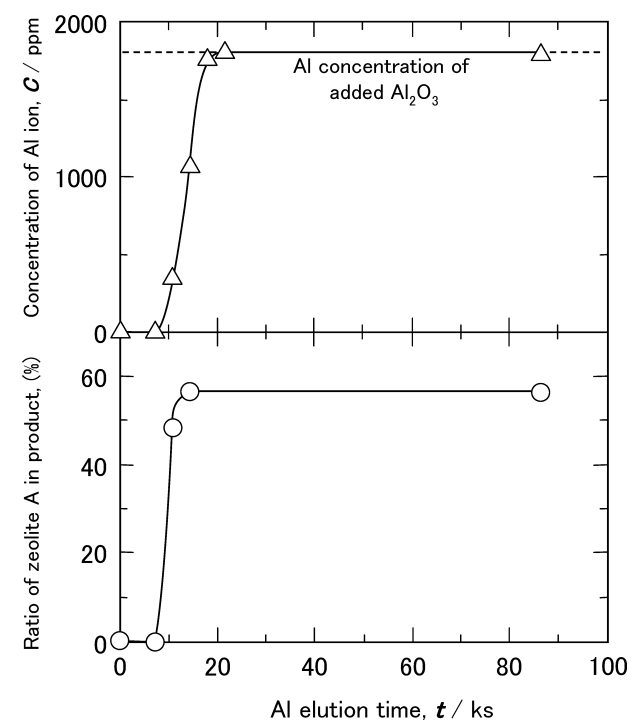

Fig. 5. Changes in $\mathrm{Al}$ ion concentration released from $\mathrm{Al}_{2} \mathrm{O}_{3}$ by $\mathrm{Al}$ elution treatment and the ratio of zeolite $\mathrm{A}$ in product with $\mathrm{Al}$ elution time. Synthesis and $\mathrm{Al}$ elution treatments were conducted at $373 \mathrm{~K}$ for $14.4 \mathrm{ks}$ and at $473 \mathrm{~K}$ in $3 \mathrm{~mol} / \mathrm{L} \mathrm{NaOH}$ solution, respectively.

The formation of zeolite A was first identified after the elution time of $10.8 \mathrm{ks}$, when the concentration of $\mathrm{Al}$ ion was $340 \mathrm{ppm}$. A further increase in the elution time leads to an increase in the ratio of zeolite A up to $56 \%$. Consequently, synthesis of zeolite A necessitates elution of $\mathrm{Al}$ ion, and the amount of this product increases with the increase of eluted $\mathrm{Al}$ ion concentration.

Figure 6 shows the effect of the time in synthesis treatment on the ratio of zeolite $\mathrm{A}$ in the product, where the elution treatment was conducted at $473 \mathrm{~K}$ for $14.4 \mathrm{ks}$. Other synthesis conditions were identical to those shown in Fig. 5. Zeolite A formed after $7.2 \mathrm{ks}$, and the ratio of zeolite A shows a peak value for $14.4 \mathrm{ks}$. The further extension in the synthesis time decreases this ratio. The crystal structures of metastable phases such as zeolite A may be change to the stable form in such an extended heating time. ${ }^{14)}$ It can be concluded from this result that the optimum time for the synthesis of zeolite A is $14.4 \mathrm{ks}$ for the case of the temperature of $373 \mathrm{~K}$ and $3 \mathrm{~mol} / \mathrm{L} \mathrm{NaOH}$ solution. Figure 7 shows changes in the product ratio of crystalline phases with the synthesis time under elution treatment at $473 \mathrm{~K}$ for $14.4 \mathrm{ks}$. Zeolite A, sodalite, and tobermorite+hydrogarnet were considered as the crystalline phases in the product, though the ratio of zeolite A in Fig. 6 was calculated directly by the calibration curve method in XRD measurements. The product ratio of the crystalline phases was calculated from the given peak of each phase; zeolite A: $2 \theta=27.08$, sodalite: $2 \theta=24.23$, and tobermorite +hydrogarnet: $2 \theta=29.07$. The product ratio of zeolite A decreases continuously with an extension of the synthesis time. The ratios of sodalite and tobermorite + hydrogarnet increase with increasing the synthesis time up to $21.6 \mathrm{ks}$. The ratio of sodalite increases in longer synthesis times, whereas the ratio of tobermorite+ hydrogarnet remains constant.

Figure 8 shows the effect of the synthesis time periods on the product ratio of the crystalline phases under both synthesis solutions of $1 \mathrm{~mol} / \mathrm{L}$ and $5 \mathrm{~mol} / \mathrm{L} \mathrm{NaOH}$. The elution time was $86.4 \mathrm{ks}$, and the temperatures in the $\mathrm{Al}$

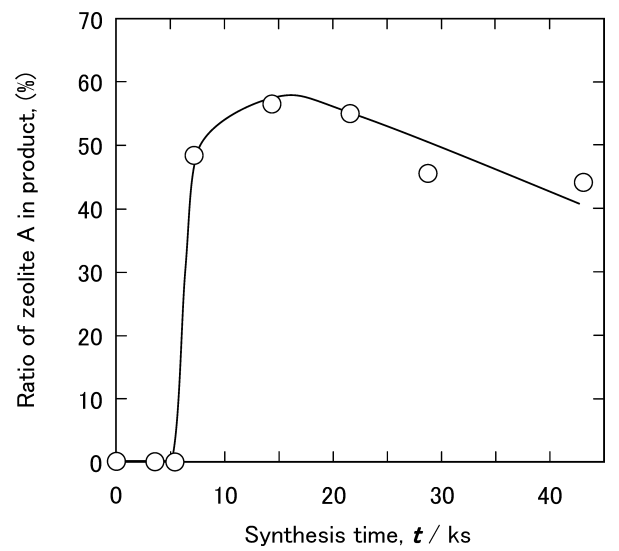

Fig. 6. The change in zeolite A content in products with synthesis time in $3 \mathrm{~mol} / \mathrm{L} \mathrm{NaOH}$ solution after $\mathrm{Al}$ elution treatment at $473 \mathrm{~K}$ for $14.4 \mathrm{ks}$.

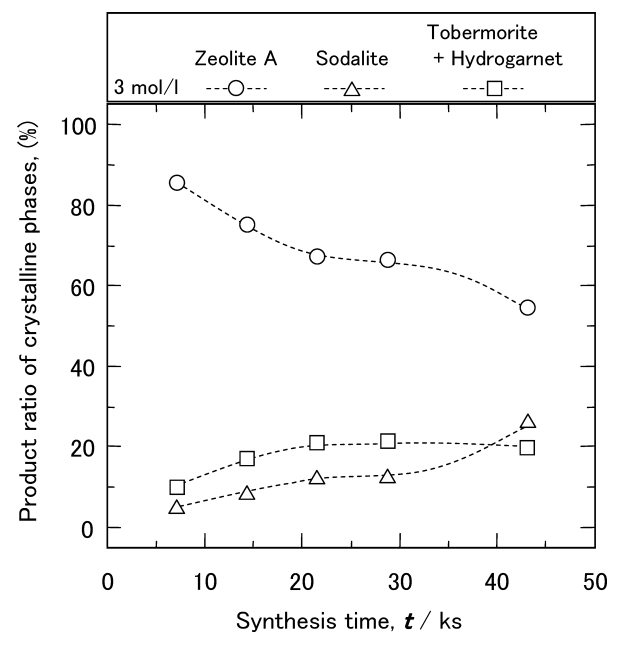

Fig. 7. The change in the ratio of product phases with synthesis time at $373 \mathrm{~K}$ after $\mathrm{Al}$ elution treatment at $473 \mathrm{~K}$ for $14.4 \mathrm{ks}$.

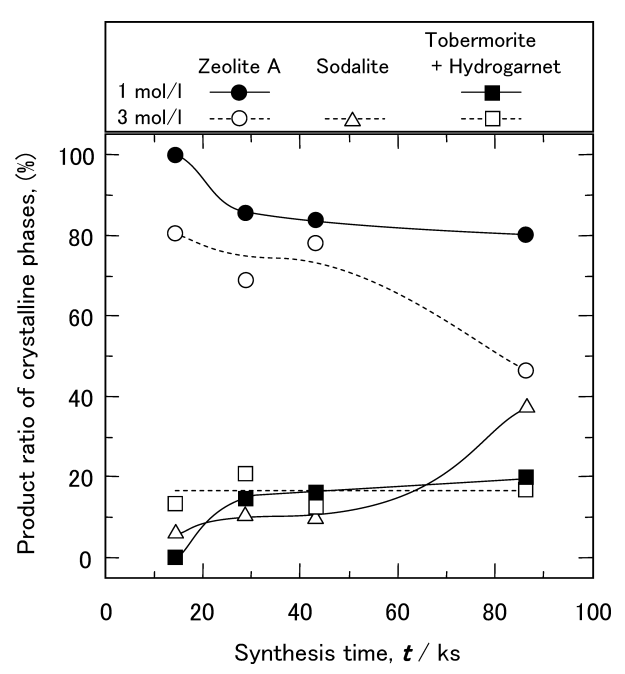

Fig. 8. The change in the ratio of product phases with synthesis time at $373 \mathrm{~K}$ after $\mathrm{Al}$ elution treatment at $473 \mathrm{~K}$ for $86.4 \mathrm{ks}$ in (a) $1 \mathrm{~mol} / \mathrm{L}$ and (b) $3 \mathrm{~mol} / \mathrm{L} \mathrm{NaOH}$ solution.

elution and synthesis treatments were $473 \mathrm{~K}$ and $373 \mathrm{~K}$, respectively. When $1 \mathrm{M} \mathrm{NaOH}$ solution was used, tobermorite+hydrogarnet was not produced in the synthesis time of $14.4 \mathrm{ks}$. It seems that the concentration of $\mathrm{Ca}$ ions in the 
solution was not sufficiently high for the formation of these phases. The ratio of these phases increases with an increase in the synthesis time from 14.4 to $28.8 \mathrm{ks}$. The reason may be that the concentration of $\mathrm{Ca}$ ions was sufficiently high for the reactions to proceed. On the other hand, when the $3 \mathrm{~mol} / \mathrm{L} \mathrm{NaOH}$ solution was used, the synthesis time has no effect on the ratio of these phases. Under these conditions, sodalite was also formed, and its ratio increases with increasing the synthesis time periods. It seems that zeolite A was transformed to sodalite as a stable phase during an extension of the synthesis time.

The effect of the synthesis temperature on the product ratio of the crystalline phases is shown in Fig. 9. The concentration of $\mathrm{NaOH}$ in the solution was $3 \mathrm{~mol} / \mathrm{L}$, and the time periods of elution and synthesis treatments were $14.4 \mathrm{ks}$ and $7.2 \mathrm{ks}$, respectively. The product ratio of zeolite A decreases at the synthesis temperature over $383 \mathrm{~K}$, whereas the product ratio of sodalite increases. On the other hand, the product ratio of tobermorite + hydrogarnet was independent of the synthesis temperature. At temperatures below $363 \mathrm{~K}$, only the amorphous phase was obtained. Therefore, it is clear that the optimum temperature for the synthesis of zeolite A is a narrow range from 373 to $383 \mathrm{~K}$.

Hence, it is concluded that zeolite A can be synthesized by a two-step method using BF slag, amorphous $\mathrm{SiO}_{2}$, and $\mathrm{Al}_{2} \mathrm{O}_{3}$ powders, where the $\mathrm{Si} / \mathrm{Al}$ molar ratio was 1.0 , and the content of $\mathrm{CaO}$ and $\mathrm{MgO}$ was less than 15 mass\%. The optimum conditions for the synthesis of zeolite $\mathrm{A}$ are that the concentration of $\mathrm{NaOH}$ in the solution is $3 \mathrm{~mol} / \mathrm{L}$, and the temperature and time of elution treatment are $473 \mathrm{~K}$ and $14.4 \mathrm{ks}$ and those of synthesis treatment are $373-383 \mathrm{~K}$ and $14.4 \mathrm{ks}$, respectively.

Figure 10 shows the scanning electron micrographs of zeolite A obtained from (a) the two-step method using optimal conditions, (b) the direct method using $\mathrm{NaAlO}_{2}$, and (c) commercial zeolite A. The synthesized zeolite A crystals obtained from the two-step method have a similar cubic shape to that of commercial zeolite A and zeolite A crystals obtained using the direct method. However, the synthesized crystals are smaller than the commercial crystals. This may be attributed to the short synthesis time and the ball-milling

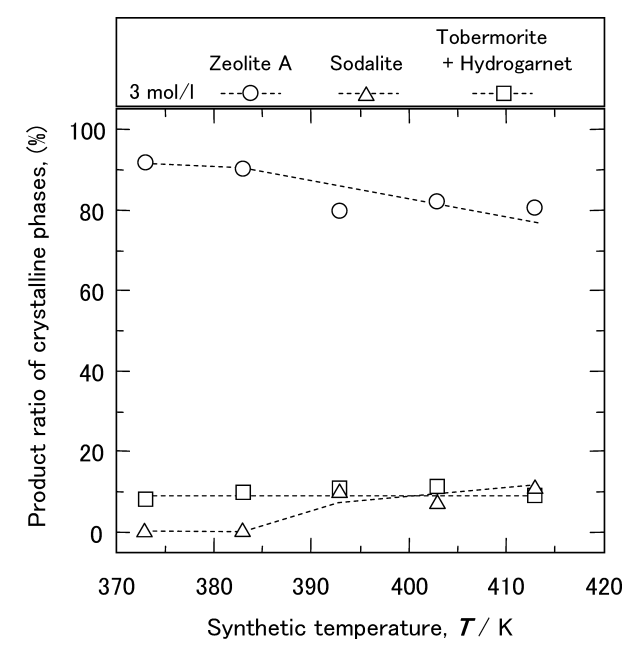

Fig. 9. The effect of synthesis temperature on the ratio of product phases obtained by synthesis for $7.2 \mathrm{ks}$ after $\mathrm{Al}$ elution treatment at $473 \mathrm{~K}$ for $14.4 \mathrm{ks}$ in $3 \mathrm{~mol} / \mathrm{L} \mathrm{NaOH}$ solution. type of reaction vessel that was used in the synthesis of zeolite A.

\subsection{Synthesis of Zeolite A Using Al Dross Residue}

The two-step synthesis of zeolite A was carried out using dross residue as an $\mathrm{Al}$ source. The concentration of $\mathrm{NaOH}$ in the solution was $3 \mathrm{~mol} / \mathrm{L}$. The temperature and time in the first and second steps were $473 \mathrm{~K}$ and $14.4 \mathrm{ks}$ and $373 \mathrm{~K}$ and $7.2 \mathrm{ks}$, respectively. Figure 11 shows the XRD patterns of the product and the dross residue. The components of the dross residue were identified as $\mathrm{Al}, \mathrm{AlN}, \mathrm{MgAl}_{2} \mathrm{O}_{4}$, and $\mathrm{MgO}$. The major compound in the product was zeolite A. Tobermorite and hydrogarnet slightly formed similarly to use of $\mathrm{Al}_{2} \mathrm{O}_{3}$ as the $\mathrm{Al}$ source. $\mathrm{MgAl}_{2} \mathrm{O}_{4}$ was also present after the reaction was complete, indicating that the $\mathrm{Al}$ source in the dross residue was not fully consumed during

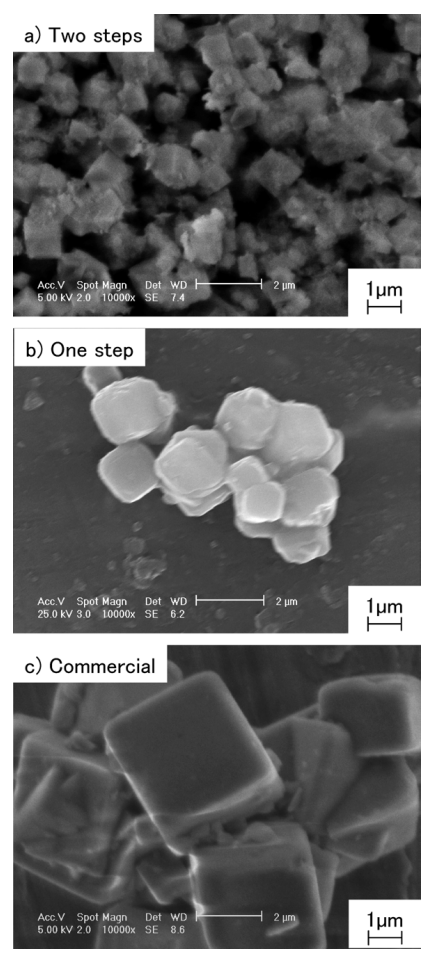

Fig. 10. Scanning electron micrographs of synthesized zeolite A by (a) two-step synthesis method and (b) direct synthesis method and (c) commercial zeolite A.

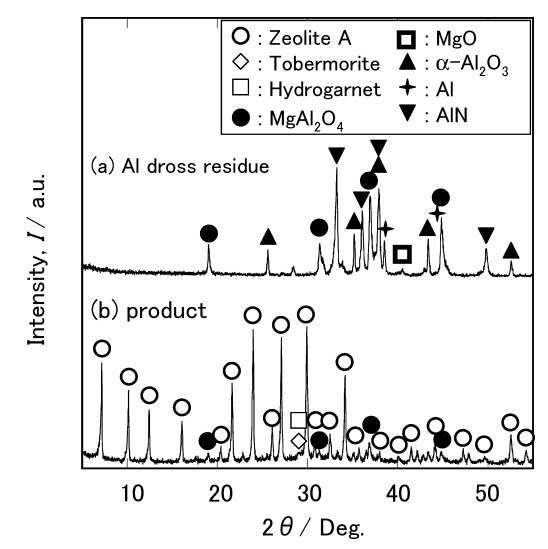

Fig. 11. XRD patterns of (a) Al dross residue and (b) products obtained by tow-step synthesis method using aluminum dross. 


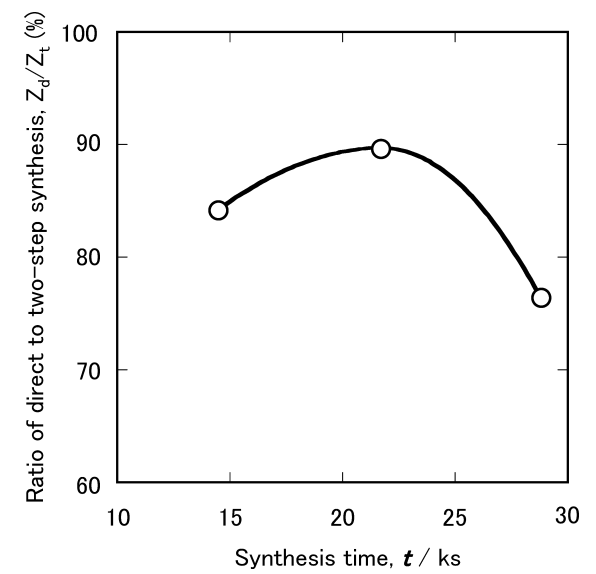

Fig. 12. The effect of synthesis time in the direct synthesis method on the ratio of zeolite A ratio in the products obtained by direct to two-step methods. Two-step synthesis was carried out in $3 \mathrm{~mol} / \mathrm{L} \mathrm{NaOH}$ solution, and the temperature and time of $\mathrm{Al}$ elution and synthesis treatments were at $473 \mathrm{~K}$ for $14.4 \mathrm{ks}$, and at $373 \mathrm{~K}$ for $7.2 \mathrm{ks}$, respectively.

the synthesis treatment. In this case, the ratio of zeolite A in the product was $60 \%$, which is slightly higher than that synthesized by the two-step method using $\mathrm{Al}_{2} \mathrm{O}_{3}$.

Figure 12 shows the change in the volume ratio of zeolite $\mathrm{A}$ in the product obtained by the direct synthesis to that by the two-step one using dross residue. The two-step synthesis was carried out using $3 \mathrm{~mol} / \mathrm{L} \mathrm{NaOH}$ solution. The temperature and time of elution and synthesis treatments were $473 \mathrm{~K}$ for $14.4 \mathrm{ks}$ and $373 \mathrm{~K}$ for $7.2 \mathrm{ks}$, respectively. Direct synthesis was carried out in $3 \mathrm{~mol} / \mathrm{L} \mathrm{NaOH}$ solution at $373 \mathrm{~K}$. The synthesis time was varied in the range from 14.4 to $28.8 \mathrm{ks}$ in both treatments. The ratio of zeolite A shows a peak value for $21.6 \mathrm{ks}$, but only $90 \%$ of the amount of zeolite A produced by the two-step synthesis was generated in direct synthesis treatment. This is because $\mathrm{Al}_{2} \mathrm{O}_{3}$, which is $9 \%$ of the dross residue, does not dissolve in the solution for the synthesis, though Al source originated from metallic Al and AlN could be used for the synthesis. Consequently, it was found that the two-step synthesis method using dross residue increased the production of zeolite A as compared to the direct synthesis.

Figure 13 shows the scanning electron micrographs of the product obtained from the two-step synthesis of zeolite A using the dross residue. Particles of zeolite A are indicated by the white arrow. The shape of these particles is the same as that synthesized using $\mathrm{Al}_{2} \mathrm{O}_{3}$, as shown in Fig. 10(a). The size of these is smaller than that of commercial zeolite A particles. However, part of the produced particles has same size as that of commercial one as shown in Fig. 13(a).

\subsection{Heat of Water Adsorption of the Product}

Figure 14 shows the relation between the heat of water adsorption of the products and the ratio of zeolite A. The products were obtained by the two-step synthesis treatment. The two-step synthesis was carried out in $3 \mathrm{~mol} / \mathrm{L} \mathrm{NaOH}$ solution, and the temperature and time of the first and second steps were $473 \mathrm{~K}$ and $14.4 \mathrm{ks}$ and $373 \mathrm{~K}$ and $7.2 \mathrm{ks}$, respectively. The heat of water adsorption of the commercial
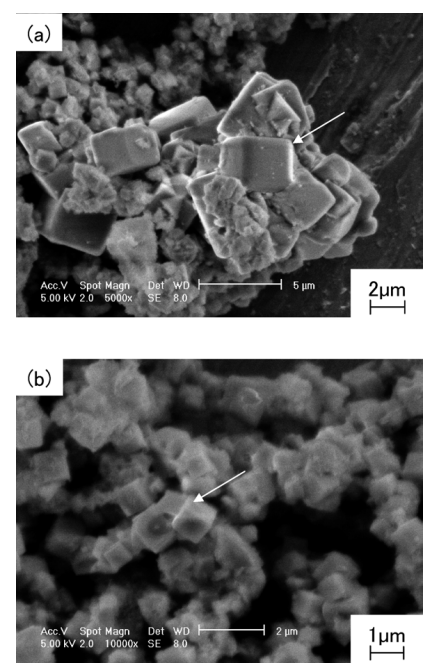

Fig. 13. Scanning electron micrographs of the product obtained by two-step hydrothermal treatment using the dross residue.

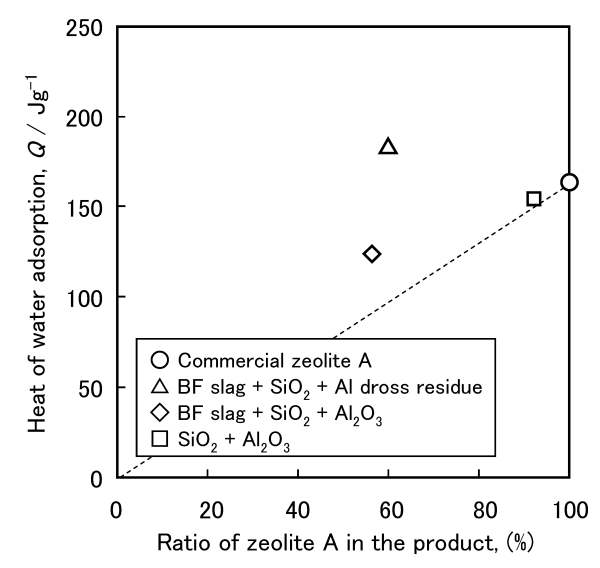

Fig. 14. Relation between heat of water adsorption of the products and ratio of zeolite A. The products were obtained by two-step synthesis.

zeolite A is $164 \mathrm{~J} \cdot \mathrm{g}^{-1}$. A proportional relationship between the heat of water adsorption and the ratio of zeolite A was not observed. The heat of water adsorption of all products in this study becomes higher than that predicted by the proportional relation. When zeolite $\mathrm{A}$ is prepared from $\mathrm{SiO}_{2}$ and $\mathrm{Al}_{2} \mathrm{O}_{3}$, the difference between the measured and the predicted values is small. However, a large difference is observed when BF slag is used to prepare zeolite A. The heat of adsorption of the product obtained using BF slag, amorphous $\mathrm{SiO}_{2}$, and the dross residue is $184 \mathrm{~J} \cdot \mathrm{g}^{-1}$, which is greater than the heat of adsorption of commercial zeolite A.

\section{Discussion}

\subsection{Evaluation of By-products as Raw Materials for Zeolite A Synthesis}

In this study, oxide by-products were used as raw materials for the synthesis of zeolite A. The formation ratio of zeolite A in the product depended a great deal on the character of raw materials including by-products. Therefore, the availability of by-products as the raw materials will be discussed in the following paragraph. 


\subsubsection{Blast Furnace Slag}

The amount of BF slag or its ratio to total amount raw material powders, which can be utilized in hydrothermal treatment for synthesis of zeolite A, is very important from point of view of its recycle use. From the previous study, ${ }^{6}$ it was found that the decrease of $\mathrm{CaO}$ content in raw material powders in use of BF slag was essentially needed to synthesize zeolite A. Under the optimum conditions, the addition ratio of BF slag has to be controlled less than $30 \%$ of the raw materials. The method to utilize more BF slag should be developed.

\subsubsection{Al Dross Residue as an Al Source}

It is difficult to synthesize zeolite A using only the Al dross residue because $\mathrm{SiO}_{2}$ content in the $\mathrm{Al}$ dross residue is very low. Therefore, in this study, the $\mathrm{Al}$ dross residue was used as an $\mathrm{Al}$ source. The surface of the dross residue particles obtained from the production of $\mathrm{Al}$ alloy series of $\# 1000$ is covered with an $\mathrm{Al}_{2} \mathrm{O}_{3}$ layer. The dross residue surfaces originated from Al alloy series of \#5000 and \#6000 alloys, which contain $\mathrm{Mg}$ as an alloying element, are coated with $\mathrm{Al}_{2} \mathrm{O}_{3}, \mathrm{MgAl}_{2} \mathrm{O}_{4}$, and $\mathrm{MgO}$ layers, while $\mathrm{AlN}$ is contained in the subsurface layer. ${ }^{15)}$ The dross residue used in this study contained 20 mass $\%$ of $\mathrm{MgAl}_{2} \mathrm{O}_{4}$. Therefore, this dross residue appears to be originated from the refining process of $\mathrm{Al}$ alloy series of $\# 5000$ and \#6000. The dross residue containing $\mathrm{Mg}$ is unsuited for use as an $\mathrm{Al}$ source for the synthesis of zeolite $\mathrm{A}$ because $\mathrm{MgAl}_{2} \mathrm{O}_{4}$ is very stable and does not dissolve during the elution treatment at $473 \mathrm{~K}$ for $86.4 \mathrm{ks}$. On the other hand, residues that do not contain $\mathrm{Mg}$, such as \#1000 alloys, are the most suitable raw materials for the synthesis of zeolite A.

\subsection{Transformation of Zeolite A to a Stable Phase}

In this study, the percentage of sodalite presented as a stable phase increased with increasing the synthesis time, temperature, and the $\mathrm{NaOH}$ concentration. As previously described, the major product obtained by the direct synthesis of zeolite A under high ratio of solution to powder material was sodalite. $\left.{ }^{6}\right)$ Many researchers have investigated the transformation of zeolite A to sodalite. Subotic et al. ${ }^{16)}$ reported that zeolite A transformed to zeolite $\mathrm{P}$ in $1 \mathrm{~mol} / \mathrm{L}$ $\mathrm{NaOH}$ solution and to hydroxysodalite under high concentrations of $\mathrm{NaOH}$. Walton et al. ${ }^{17)}$ reported that higher temperatures and concentrations of $\mathrm{NaOH}$ resulted in the transformation of zeolite A to hydroxysodalite in a shorter period of time. At higher temperatures, the direct formation of sodalite, but not zeolite A, was reported by Breuer et al. ${ }^{18)}$ The results presented in this study are in agreement with those reported previously.

\subsection{Relation between the Heat of Water Adsorption and the Production Ratio of Zeolite A}

The reason why the heat of water adsorption of zeolite A produced by the two-step synthesis is larger than that predicted by the proportional relation described above will be discussed. Basaldella et al. ${ }^{19)}$ reported that zeolite A particles synthesized in solutions with high $\mathrm{Al}$ concentration showed the cubic with beveled edges. Zeolites A particles synthesized by the two-step method shown in Figs. 10 and
13 have beveled edges. It is estimated that zeolite A with high $\mathrm{Al}$ content, namely low $\mathrm{Si} / \mathrm{Al}$ ratio, was synthesized because the concentration of $\mathrm{Al}$ ions in the solution at the beginning of the synthesis treatment was high as shown in Fig. 5. On the other hand, commercial zeolite A does not have beveled edges. It means that $\mathrm{Si} / \mathrm{Al}$ ratio of commercial zeolite A is high.

It is known that the $\mathrm{Si} / \mathrm{Al}$ ratio in zeolite has the marked effect on the hydrophilic property of zeolite. ${ }^{20)}$ Zeolite becomes more hydrophilic with an increase in the Al content. It is concluded that the reason why the heat of water adsorption of the product was greater than the predicted value is that the $\mathrm{Si} / \mathrm{Al}$ ratio of the synthesized zeolite $\mathrm{A}$ is less than that of commercial zeolite A. Further, not only the formation of zeolite A but also that of tobermorite and hydrogarnet, which had a certain heat storage capacity, ${ }^{6)}$ was detected. This is also one of reasons why the products have greater heats of water adsorption. Therefore, it is concluded that products containing tobermorite and hydrogarnet can be used as heat storage materials.

\section{Conclusions}

The alkali hydrothermal synthesis of zeolite A using oxide by-products such as BF slag and Al dross residue was studied, and the following results were obtained:

(1) Zeolite A could be successfully synthesized using BF slag, amorphous $\mathrm{SiO}_{2}$, and $\mathrm{Al}_{2} \mathrm{O}_{3}$ by applying a twostep synthesis method, which consists of an $\mathrm{Al}_{2} \mathrm{O}_{3}$ elution process and a synthesis process. The optimum condition for this method is that the concentration of $\mathrm{NaOH}$ in solution is $3 \mathrm{~mol} / \mathrm{L}$, the temperature and time of first and second steps are $473 \mathrm{~K}$ and $14.4 \mathrm{ks}, 373-383 \mathrm{~K}$ and $14.4 \mathrm{ks}$, respectively. The ratio of zeolite $\mathrm{A}$ in the synthesized product was $56 \%$ under the optimum condition.

(2) The dross residue was found to be used as an Al source for the synthesis of zeolite A. Although zeolite A can be synthesized directly, the amount of zeolite A in the product increases when the two-step method is used. However, the percent yield of zeolite A was not $100 \%$ on account of the presence of $\mathrm{CaO}$ and $\mathrm{MgO}$ in the $\mathrm{BF}$ slag and $\mathrm{MgAl}_{2} \mathrm{O}_{4}$ in the dross residue.

(3) The heat of water adsorption of the product synthesized by the two-step method using BF slag, amorphous $\mathrm{SiO}_{2}$, and the dross residue is greater than $180 \mathrm{~J} \cdot \mathrm{g}^{-1}$. The obtained heat is larger than that of commercial zeolite A. The heats of water adsorption for all products prepared by the two-step synthesis are greater than the predicted values. This discrepancy is explained by difference in the $\mathrm{Si} / \mathrm{Al}$ ratio in zeolite $\mathrm{A}$.

\section{REFERENCES}

1) T. Mizota: J. Jpn. Inst. Energy, 80 (2001), 916.

2) D. W. Breck, W. G. Eversole, R. M. Milton, T. B. Reed and T. L. Thomas: J. Am. Chem. Soc., 78 (1956), 5963.

3) S. J. Tae and K. Morita: ISIJ Int., 47 (2007), 1813.

4) T. Yoshikawa, S. Hirano, N. Hirai and T. Tanaka: ISIJ Int., 48 (2008), 1322.

5) Y. Kuwahara, T. Ohmichi, T. Kamegawa, K. Mori and H. Yamashita: J. Mater. Chem., 19 (2009), 7263.

6) Y. Sugano, R. Sahara, T. Murakami, T. Narushima, Y. Iguchi and C. Ouchi: ISIJ Int., 45 (2005), 937. 
ISIJ International, Vol. 51 (2011), No. 1

7) H. Mimura, K. Yokota, K. Akiba and Y. Onodera: J. Nucl. Sci. Technol., 38 (2001), 766.

8) N. Murayama, H. Yamamoto and J. Shibata: Int. J. Miner. Process., 64 (2002), 1.

9) N. Murayama, H. Yamamoto and J. Shibata: J. Chem. Technol. Biotechnol., 77 (2002), 280

10) G. G. Hollman, G. Steenbruggen and M. Janssen-Jurkovicová: Fuel, 78 (1999), 1225.

11) H. Tanaka, T. Sakai and R. Hino: Mater. Res. Bull., 37 (2002), 1873.

12) O. J. Kleppa: J. Phys. Chem., 64 (1960), 1937.

13) T. Muraki, T. Narushima and Y. Iguchi: ISIJ Int., 36 (1996), S243.

14) M. C. Barnes, J. A. Mensah and A. R. Gerson: Micropor. Mesopor.
Mater, 31 (1999), 287.

15) S. Fukumoto, T. Hookabe and H. Tsubakino: J. Jpn. Inst. Light Met., 50 (2000), 392.

16) B. Subotic, D. Skritic, I. Smit and L. Sekovanic: J. Cryst. Growth, 50 (1980), 498.

17) R. I. Walton, R. I. Smith and D. O'Hare: Micropor. Mesopor. Mater., 48 (2001), 79.

18) R. G. Breuer, L. R. Barsotti and A. C. Kelly: Extractive Metallurgy of Aluminium, Interscience, New York, (1963), 133.

19) E. I. Basaldella, A. Kikot and J. C. Tara: Mater. Lett., 31 (1997), 83.

20) G. Majano, L. Delmotte, V. Valtchev and S. Mintova: Chem. Mater., 21 (2009), 4184. 